\title{
Potential forage value of some eastern Canadian sedges (Cyperaceae: Carex)
}

\author{
P.M. CATLING, A.R. MCELROY, AND K.W. SPICER
}

\begin{abstract}
Authors are research scientist, Centre of Land and Biological Resources Research; research scientist, Plant Research Centre; and senior technician. Centre for Land and Biological Resources Research, Agriculture Canada, Central Experimental Farm, Ottawa K1A 0C6, Canada.
\end{abstract}

\begin{abstract}
The relationship between forage value and various factors, including sectional classification, species, moisture, light, and date and year of collection, was explored with analysis of variance in 317 collections representing 77 species of Carex. Most of the sedges analyzed would exceed the energy required for livestock maintenance. There was great variability within and between species and sections in forage values defined in terms of crude protein, acidpepsin digestibility, and acid detergent fibre content. Some species, such as $C$. praegracilis, have crude protein levels of about $15 \%$, acid-pepsin digestibility exceeding $33 \%$, and acid detergent fibre less than 33\%, making them equivalent to a good quality grass hay. It was not possible to make generalizations about correlation with light and moisture, but rhizomatous species had higher acid-pepsin digestibility $(P<0.10)$ and lower acid detergent fibre $(P<0.01)$ than crespitose species. Forage quality was highest in the beginning of the season. Crude protein decreased 0.04 to $0.09 \%$ units/day and acid-pepsin digestibility declined 0.06 to 0.11 units/day. In 2 of the the 3 years, acid detergent fibre increased significantly $(P<0.01)$ over time. The classification system appears to be useful in identifying species and species groups with the greatest forage potential. Some sedge species with relatively low forage value are nevertheless utilized by cattle. Natural habitats and native forages, such as sedges, may be far more valuable than is currently realized, and the trend toward increasingly efficient landscape use will require $a$ better understanding of their value and management.
\end{abstract}

Key Words: crude protein, digestibility, fibre, taxonomic and seasonal variation, native forage

In western North America, sedges (genus Carex, family Cyperaceae) are important as food for both domestic animals (e.g., Hermann 1970, Uresk 1986) and wildlife (Fox 1991, Kufeld 1973, Looman 1983, Roberts 1983). For example, in Colorado and Wyoming, smaller sedges of dry ground including Carex eleocharis, when available, are among the major forage items found in cattle diets, and they are highly preferred by cattle (Uresk 1986). In Yukon rangelands the tall wetland species, Carex atherodes and Carex rostrata, are important forage producing plants (Bailey et al. 1992). Among the food items of Rocky Mountain elk (Cervus canadensis canadensis), only 1 plant species of the 313 reported was rated as highly valuable throughout the year and that was the sedge C. geyeri (Kufeld 1973). Although the eastern Canadian sedges are widely utilized as components of pasture and are sometimes harvested as hay (e.g., Rousseau 1934, Séguin 1975), their

\footnotetext{
Dr. A.A. Reznicek, University of Michigan, kindly corrected some of the Carex determinations, and Drs. J. Cayouette and E. Small of Agriculture Canada provided useful comments on the manuscript.

Manuscript accepted 8 Dec. 1993.
}

value to livestock is less well known. To the extent that they dominate plant communities like the western species, the eastern sedges are important to wildlife, including for example snow geese (Chen caerulescens) (e.g., Kotamen and Jefferies 1989) and Canada geese (Branta canadensis) (Dignard et al. 1991). The purpose of the work reported here was to determine the potential forage value of eastern Canadian sedges. We include consideration of variation as well as taxonomic and ecological relationships, so as to provide information on species and on trends within this group of plants that may prove useful in range management. Potential rather than actual forage values are the subject of the present work because aspects such as chemical composition causing unpalatability are not taken into account.

\section{Materials and Methods}

\section{Data Collection}

From 1987 to 1989,317 collections of Carex were made within $30 \mathrm{~km}$ of Ottawa in eastern Ontario. Vouchers for all collections were deposited in the vascular plant herbarium (DAO) of Agriculture Canada in Ottawa. The authorities for names (Table 1) and additional information are available in current botanical texts (e.g., Morton and Venn 1990). The only confusion in names arises in section Bracteosae where $C$. radiata is $C$. rosea in the sense of MacKenzie (1931) and recent authors and $C$. rosea is $C$. convoluta in the sense of MacKenzie (1931) and recent authors (see Webber and Ball 1984). In general the plants were collected at the stage of early maturity when the perigynia were well developed. In some cases, such as with $C$. praegracilis, collections were made at different times in an attempt to determine seasonal variation.

Samples were dried at $55^{\circ} \mathrm{C}$ and ground in a Wiley mill equipped with a 1-mm screen. Those collected in $1987(n=42)$ were analyzed for acid-pepsin digestibility and acid detergent fibre, while those collected in 1988 and 1989 ( $n=155$ and 120, respectively) were analyzed for crude protein, acid-pepsin digestibility and acid detergent fibre. Crude protein was determined as Kjeldahl $\mathbf{N} \times$ 6.25. For acid-pepsin digestibility determinations, approximately $0.30 \mathrm{~g}$ of material was placed in tared $200 \mathrm{ml} \mathrm{screw-top}$ culture tubes, dried to constant weight at $90^{\circ} \mathrm{C}$, and weighed. To each tube was added $25 \mathrm{ml}$ of $0.25 \%$ pepsin solution in $0.1 \mathrm{~N} \mathrm{HCl}$. The tubes were maintained at $39^{\circ} \mathrm{C}$ and agitated slowly by complete inversion (approximately $1 \mathrm{rpm}$ ) for 24 hours. The sample was then filtered through a tared $\# 1$ Whatman filter paper, dried to constant weight at $100^{\circ} \mathrm{C}$, and the percent dry matter loss was determined. Acid detergent fibre was determined using the method of Goering and van Soest (1970). All chemical analyses were made in duplicate and mean values were used for statistical analysis. Statistical analysis was performed using the General Linear Models procedures of 


\section{SAS (SAS Institute 1985).}

To determine whether there were trends in forage value associated with ecological characteristics of the plants, all species were coded on a scale of 1 to 3 for moisture habitat (wet, mesic, and dry soils) and a scale of 1 to 3 for light habitat (open, semishaded, or completely shaded). The relationships of growth habitat (rhizomatous or caespitose), moisture, and light habitat with quality parameters were examined in a single analysis since there was considerable confounding among treatment effects. Species means were used in the analysis in order to avoid any bias due to the uneven sample numbers. Least-square means were calculated for each factor. An initial analysis revealed that there were no interactions among the factors for any quality parameter, so a main effects model was used with significance of effects being based on Type III SS of SAS.

The overall effects of year and date of sampling on sedge quality were examined using the complete data set. Significant $(P<0.01)$ year effects were found for crude protein and acid detergent fibre, but differences among means were too small to be of practical importance. A preliminary analysis revealed the presence of date and date within year effects, so regression analyses of quality parameters on Julian date of harvest were conducted for each year. Linear, quadratic, and higher order effects were evaluated using the GLM procedure of SAS (SAS Institute 1985). Material used to determine the effect of date on quality of Carex praegracilis was collected near Almonte, Lanark County, Ontario in 1989.

Direct observations of cattle eating sedges were recorded when samples were collected. Species eaten were compared with respect to forage quality analysis.

\section{Results}

Although equations relating acid detergent fibre to total digested nutrient (TDN) have not been developed for sedges, calculations for grass species in Ontario (TDN $(\%)=98.625-(1.048$ acid detergent fibre(\%), Ontario Ministry of Agriculture and Food, pers. comm.) suggest that most sedges would exceed the energy required for animal maintenance and would result in weight gain. This is also supported by the fact that most species have a crude protein content exceeding $8 \%$, which is adequate for animal maintenance (National Academy of Sciences-National Research Council 1984).

\section{Variation Within Taxonomic Groups}

Significant differences $(P<0.01)$ were found among taxonomic groupings for all quality parameters. The range among groupings for crude protein was from $8.3 \%$ (section Albae, $\mathrm{n}=8$ ) to $13.3 \%$ (Section Heleonastes, $\mathrm{n}=9$ ). The range among group means for acid-pepsin digestibility was 21.0 to $32.0 \%$, and for acid detergent fibre, 31.6 to $40.6 \%$. Carex praegracilis in section Divisae, section Bracteosae, and C. houghtoniana in section Lasiocarpae are of potentially high forage value. The sections Laxiflorae and Granulares are potentially valuable in terms of high acid-pepsin digestibility. The sections Ovales, Gracillimae and Vesicariae appear to be of much lesser forage value due to relatively low crude protein and acid-pepsin digestibility, accompanied by relatively high acid detergent fibre (Table 1).

Differences $(P<0.01)$ were found among species for all quality parameters as well. The higher values of crude protein and acidpepsin digestibility and lower acid detergent fibre values make some of the Carex species (e.g., C. praegracilis, C. houghtoniana) equivalent to good quality grass hay in their potential forage value. Other species, such as many in section Ovales, appear to be of more limited forage value. There is, however, substantial variation within some species. The crude protein content of $C$. praegracilis, for example, varied from 8.1 to $16.8 \%$ and that of $C$. radiata from
7.8 to $18.3 \%$. The factors affecting crude protein levels were not determined, but it is to be expected that harvest date, phenological age, and micro-environment effects all played a role.

\section{Relationships with Growth Habit, Moisture, and Light}

Light regime effects $(P<0.05)$ were detected only for crude protein level. The means and standard errors for the groups 1,2 , and 3 were $10.2 \pm .39,10.5 \pm .55$, and $12.3 \pm .63$, respectively. Therefore, although the species growing under complete shade had higher crude protein levels than those in open or semishaded habitats, the difference is too small to be of practical importance. No effects were detected for moisture regime. Growth habitat effects were detected for acid-pepsin digestibility $(P<.10)$ and acid detergent fibre $(P<0.01)$ only. Rhizomatous species had higher acid-pepsin digestibility $(27.9 \pm 1.10$ vs $25.8 \pm 0.47)$ and lower acid detergent fibre ( $33.1 \pm 0.96$ vs $36.1 \pm 0.41)$ than caespitose species. Therefore, for the species sampled, differences based on moisture habitat or light regime were either not detected or small, but the rhizomatous species had a higher potential feed value.

\section{Effects of Year and Date}

Crude protein and acid-pepsin digestibility declined and acid detergent fibre increased throughout the summer. Crude protein declined in a linear fashion in 1988, at an average rate of $0.04 \%$ units per day (Table 2). In 1989, the relationship between crude protein and time was described by a significant $(P<0.01)$ linear component and a higher level polynomial that was not investigated. The quadratic effect was not significant $(P>0.10)$. The average rate of crude protein decline was 0.9 units per day. Acidpepsin digestibility declined linearly in all years, ranging from 0.06 to 0.11 units per day. Acid detergent fibre did not change significantly with time in 1987, but increased with time in the following 2 years. In 1988, the relationship was quadratic, increasing more rapidly early in the season, but the linear component $(P<0.01)$ accounted for over $65 \%$ of the variation accounted for by the model. Acid detergent fibre rose linearly in 1989 at an average of 0.09 units per day. It is not clear from this analysis whether these observations are the result of declining forage quality with advance in maturity of individual species, the effects of weather changes throughout the growing season, or the sequence of species being harvested. Nevertheless, if the samples collected are assumed to be a reasonable representation of the sedge forage available for grazing during the summer, it appears that the overall quality of sedges in substantially higher at the beginning of the season.

Collection dates of $C$. praegracilis ranged from mid-May to mid-July. A preliminary analysis indicated that year did not have a significant effect on any quality parameter. Data for 8 collections on 5 dates in 1989 shows a decline in crude protein and acid-pepsin digestibility in late May early June and a corresponding increase in acid detergent fibre over the same period, after which all of the forage characteristics essentially levelled off until late summer (Fig. 1).

\section{Utilization by Cattle}

Direct consumption by cattle was noted for 17 of the 77 species listed in Table 1 (as shown). These observations include some species, like $C$. radiata, that have relatively high protein and acidpepsin digestibility and relatively low acid detergent fibre, as well as some like $C$. bebbii and $C$. vulpinoidea which were found to have relatively low protein and acid-pepsin digestibility, and high acid detergent fibre. The observations suggest that some species, for which the data suggest relatively low forage value, are still utilized, and may, in some circumstances be valuable. In no case were cattle observed avoiding sedges. 
Table 1. Percentage crude protein (CP), percentage acid-pepsin digestibility (APD) and percentage acid detergent fibre (ADF) of various species of eastern Ontario Carex. Asterisks (") after a species name indicates species which cattle were seen eating. The number of samples (n) is shown on the left. An adjacent number in brackets indicates the number of samples for CP if different from APD and ADF.

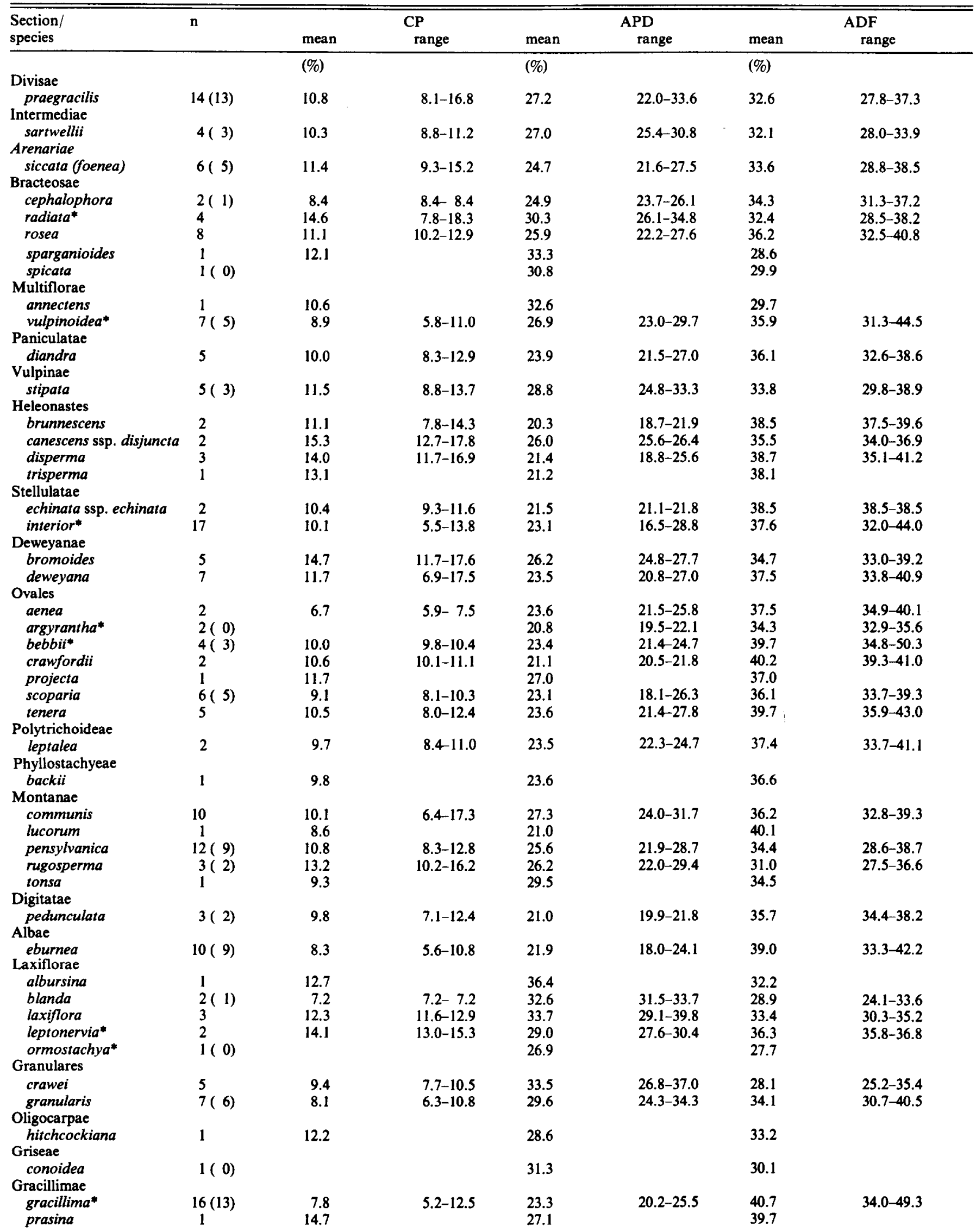


Table 1. Continued.

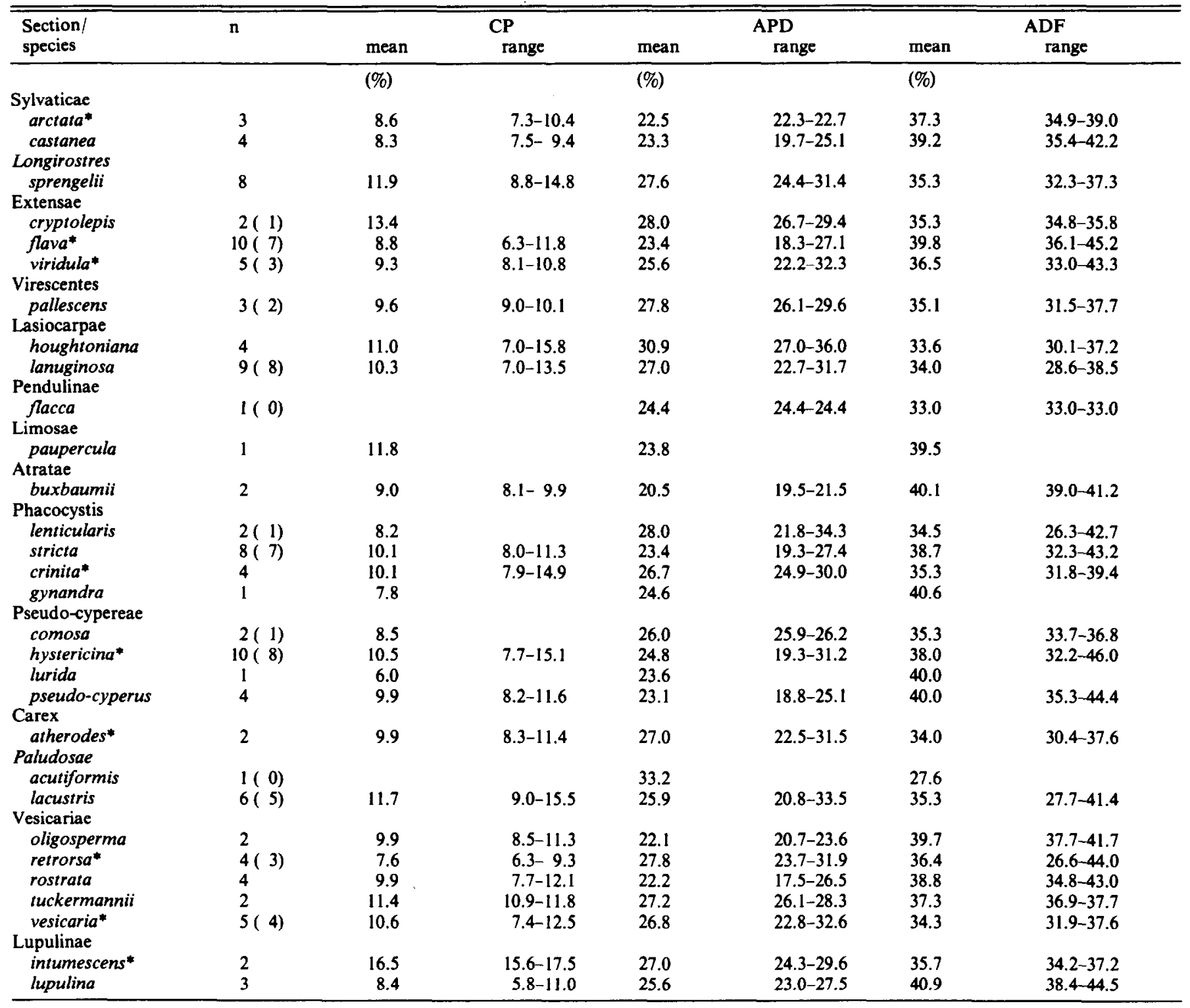

Table 2. Linear regression analysis of crude protein, acid-pepsin digestibility, and acid detergent fibre content of sedge samples on date (Julian day) of harvest in 3 years. Whether or not results were linear based on GLM procedure of SAS is indicated.

\begin{tabular}{lccc}
\hline \hline & & Year & \\
Parameter & 1987 & 1988 & 1989 \\
\hline crude & $\ldots \ldots \ldots$ & slope \pm standard error $\ldots \ldots \ldots . .$. \\
protein & - & $-0.04 \pm .01^{* *}$ & $-0.09 \pm .01^{* *}$ \\
acid- & linear & non-linear \\
pepsin digestibility & $-0.08 \pm .03^{* *}$ & $-0.11 \pm .02^{* *}$ & $-0.06 \pm .02^{* *}$ \\
acid & linear & linear & linear \\
detergent fibre & $0.02 \pm .03$ & $0.13 \pm .02^{* *}$ & $0.09 \pm .02^{* *}$ \\
& & non-linear & non-linear \\
\hline
\end{tabular}

**signifcant at $P<0.01$

\section{Discussion and Conclusions}

Clearly many eastern Canadian sedges are potentially very valuable as forage. Since there is substantial variation in the potential forage value, it follows that rangelands or natural hay may be improved through promotion of the most valuable sedge species.

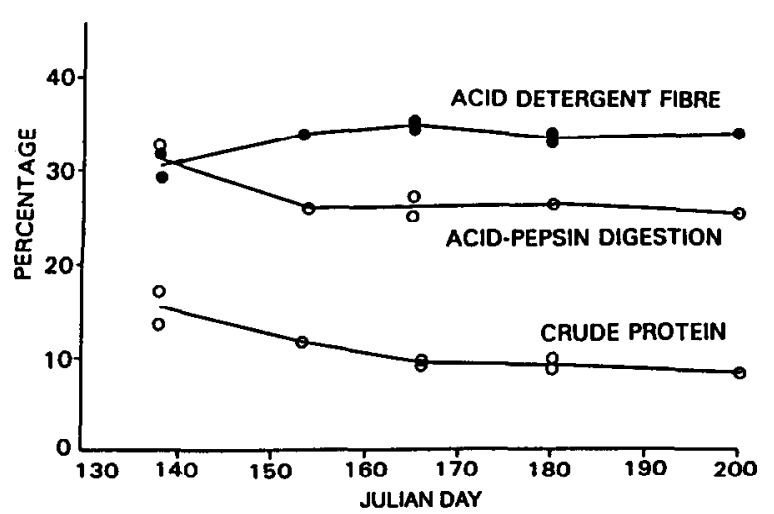

Fig. 1. Trends in forage quality parameters in Carex praegracilis collected from a single site in eastern Ontario in 1989.

Several recent authors have noted that sedges have been largely neglected by range managers (e.g., Ingvason 1969, Uresk 1986), yet the known value of some species and the known potential of many 
others, suggest that there may be substantial benefits in the effective management of rangeland sedges. The ways of promoting certain species will require more research. This study suggests that rhizomatous species are of higher quality on average, and therefore deserve the primary focus of research on sedge utilization. The trend toward more efficent landscape utilization is expected to continue and will require a better understanding of the value of native forages in general. While natural habitats may be much more valuable than is currently realized, their use as a forage should take environmental sustainability into account. In situations where protection of natural features is an important aspect, forage utilization would have to be carefully planned and monitored and may be inappropriate.

Some species of sedges have an excellent potential for promotion, propagation, or improvement. Carex praegracilis for example can be propagated from rhizome sections as well as seeds and can rapidly colonize slightly saline substrates (Reznicek \& Catling 1987). Carex atherodes, of approximately equivalent forage value (Table 1) and well known for its value in western North America, can also be reproduced from rhizome segments and is a wetland species tolerant of periodic drought (Corns 1974, Hardy BBT, Ltd. 1989). Both of these rhizomatous species are of additional value in erosion control and reclamation (Hardy BBT, Lid. 1989). Establishment of sedges for forage use does not necessarily have to involve European introductions that are not well adapted to a particular North American environment.

Future studies of forage value in sedges would be profitably directed to actual forage trials and rumen analyses, and also to a furthering of our knowledge regarding the relationship of forage value with ecological and morphological features. Also more study is needed to evaluate the extent to which the classification system is reliably predictive in indicating the groupings with the greatest forage potential.

\section{Literature Cited}

Bailey, A., M. Willoughby, R. Johansen, and S. Smith. 1992. Management of Yukon rangelands. Yukon Renewable Resources. Government of the Yukon.

Corns, W.G. 1974. Influence of time and frequency of harvests on productivity and chemical composition of fertilized and unfertilized awned sedge. Canada J. Plant Sci. 54:493-498.
Dignard, N., R. Lalumiere, A. Reed, and M. Julien. 1991. Les habitats cotiers du nord-est de la baie James. Service Canadien de la faune, no. 70.

Goering, H.K., and P.J. van Soest. 1970. Forage fibre analyses (apparatus, rcagent,s procedures, and some applications). Agr. Handbk. 379, ARSUSDA, Washington, DC

Hardy, BBT Ltd. 1989. Manual of plant species suitability for reclamation in Alberta-2nd edition. Alberta Land Cons. and Reclamation Counc. Rep. No. RRTAC 89-4.

Fox, J.L. 1991. Forage quality of Carex macrochaeta emerging from Alaskan alpine snowbanks through the summer. Amer. Midl. Natur. 126:287-293.

Hermann, F.J. 1970. Manual of the Carices of the Rocky Mountains and Colorado Basin. USDA Handb. 374:1-397.

Ingvason, P.A. 1969. The golden sedges of Iceland. World Crops: 218-220.

Kotamen, P.M., and R.L. Jefferies. 1989. Responses of article sedges to release from grazing: leaf elongation in two species of Carex. Can. J. Bot. 67:1414-1419.

Kufeld, R.C. 1973. Foods eaten by Rocky Mountain elk. J. Range Manage. 26:106-113.

Loomen, J. 1983. 111 range and forage plants of the Canadian prairies. Agr. Canada Res. Branch Pub. 1751.

MacKenzie, K.K. 1931-1935. Cyperaceae, tribe 1, Cariceae. North American Flora 18:1-478.

Morton, J.K., and J.M. Venn. 1990. A checklist of the flora of Ontario, vascular plants. Univ. Waterloo, biology series 34:1-218.

National Academy of Sciences-National Research Council. 1984. Nutrient requirements of domestic animals. Nutrient requirements of beef cattle. 6th rev. ed. NAS-NRC, Washington, DC.

Roberts, A. 1983. A field guide to the sedges of the Cariboo Forest region of British Columbia. British Columbia Ministry of Forests, Land Management Rep. 14:1-89

Rousseau, J. 1934. La batture de 1 Ile aux Gruces et son importance économique. Société de Québec pour la protection des plantes, rapport: 82-86.

Reznicek, A.A., and P.M. Catling. 1987. Carex praegracilis (Cyperaceae) in eastern North America: a remarkable case of rapid invasion. Rhodora 89:205-216.

SAS Institute, Inc. 1985. SAS user's guide: Statistics, Version 5 Ed. SAS Institute Inc., Cary, N.C.

Séguin, R.-L. 1975. La récolte du jonc de cajeu et de la rouch à 1 ile aux Oies. pp. 7-72 In: R.-L. Séguin, ed. Revue d'ethnologie due Québec.

Uresk, D.W. 1986. Food habits of cattle on mixed-grass prairie on the northern Great Plains. Prairie Natur. 18:211-218.

Webber, J.M., and P.W. Ball. 1984. The taxonomy of the Carex rosea group (section Phaestoglochin) in Canada. Can. J. Bot. 62:2058-2073. 